\title{
Water content in peanut seeds according to conditions of the storage environment
}

\author{
Nathália de Oliveira Sá, Gustavo Soares Wenneck, Reni Saath, Gabriela Cristina Ghuidotti, Giovanna \\ Gabriela Ferreira de Oliveira
}

Universidade Estadual de Maringá - UEM, PR. E-mail: gustavowenneck@gmail.com

\begin{abstract}
The conditions of the storage environment can influence the quality of seeds or grains in relation to commercial quality, deterioration and nutritional characteristics, mainly as a function of temperature and relative humidity. The objective of this study was to analyze the influence of temperature and relative humidity of storage on the water content of peanut seeds. The experiment was developed in a completely randomized design in factorial scheme $5 \times 9$, with five temperatures $\left(5,10,15,20\right.$ and $\left.25^{\circ} \mathrm{C}\right)$ and nine conditions of relative humidity, each condition had nine repetitions. The seeds were stored in airtight packaging with saturated solutions to maintain a constant condition. The water content in the seeds was evaluated in each condition. The data were subjected to analysis of variance, correlation, regression, multivariate analysis and adjustment with mathematical models. Relative humidity was more expressive in changing the equilibrium water content. The Chung-Pfost model was the most suitable to represent the sorption process in peanut seeds.
\end{abstract}

Keywords: Arachis hypogaea L.; post-harvest; sorption.

\section{Teor de água em sementes de amendoim em função das condições do ambiente de armazenamento}

\section{Resumo}

As condições do ambiente de armazenamento podem influenciar na qualidade de sementes ou grãos em relação a qualidade comercial, deterioração e características nutricionais, principalmente em função da temperatura e umidade relativa. O estudo teve como objetivo analisar a influência da temperatura e umidade relativa de armazenamento sobre o conteúdo de água em sementes de amendoim. 0 experimento foi desenvolvido em delineamento inteiramente casualizado em esquema fatorial $5 \times 9$, sendo cinco temperaturas $\left(5,10,15,20\right.$ e $\left.25^{\circ} \mathrm{C}\right)$ e nove condições de umidade relativa. Cada condição apresentava nove repetições. As sementes foram armazenadas em embalagens herméticas com soluções saturadas para manter a condição constante. Foi avaliado o teor de água nas sementes em cada condição. Os dados foram submetidos a análise de variância, correlação, regressão, analise multivariada e ajuste com modelos matemáticos. A umidade relativa foi mais expressiva na alteração do teor de água em equilíbrio. $O$ modelo de Chung-Pfost foi o mais adequado para representar o processo de sorção em sementes de amendoim.

Palavras-chave: Arachis hypogaea L., pós-colheita, sorção.

\section{Introduction}

Peanut (Arachis hypogaea L.) is an oilseed

whose chemical composition, productive characteristics and purpose of use has increased its commercial value, being a viable option for family farming (SAATH, 2021). With the fruit developed in the soil, the seeds may be subject from cultivation to attack by fungi and insects with the potential to compromise commercial quality (ROLLEMBERG et al., 2018).

In post-harvest, care with the product is related from drying, due to the change in physical and nutritional properties, to storage, in which conditions can favor the development of fungi, with the potential for sanitary and commercial 
devaluation (LARIOS; GORAYEB, 2016; MALLEKAYADI et al., 2020; SAATH et al., 2010).

Considering that the changes in the thermodynamic properties of the product are related to changes in the environment, mainly water vapor, resulting in changes in the water content that influences enzymatic processes and the development of pathogens (BUSTOSVANEGAS et al., 2018; CAMPOS et al., 2019; TUBBS et al., 2016; ZIEGLER et al., 2017). Understanding the dynamics of water in the seed becomes important to define strategies for preserving quality (AGHAZADEH et al., 2021; WENNECK et al., 2020).

During the storage period the product keeps its metabolic activities active interacting with the environment. The aim is to maximize the conservation of the quality of the product, for this it is necessary to observe both parameters of relative humidity and temperature of the environment, but also the material for storage, in order to reduce as gas exchanges with the environment, decreasing the degradation of the reserves of the products (ARAUJO et al., 2021; ZUCARELI et al., 2015). The objective of this study was to analyze the influence of temperature and relative humidity of the storage environment on the water content in peanut seeds.

\section{Materials and methods}

The study was conducted at the Laboratory of Medicinal Plants and Postharvest Technology belonging to the State University of

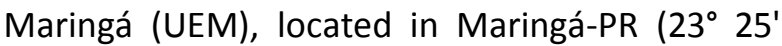
$38^{\prime \prime} \mathrm{S}$, longitude $51^{\circ} 56^{\prime} 15^{\prime \prime} \mathrm{W}$ and altitude of 551 $\mathrm{m})$. The material used came from a rural producer

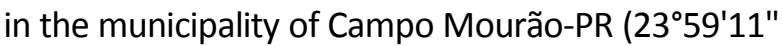
$\mathrm{S}$, longitude $52^{\circ} 29^{\prime} 52^{\prime \prime} \mathrm{W}$ and altitude of $535 \mathrm{~m}$ ).

The experimental was conducted in a completely randomized design in factorial scheme $5 \times 9$ with five temperatures $(5,10,15,20$ and 25 ${ }^{\circ} \mathrm{C}$ ) and nine relative humidity conditions (Table 1 ), with nine replications per treatment. For the control of the temperature and relative humidity, the samples were stored in biochemical oxygen demand (BOD) and to obtain the different conditions relative humidity, saturated solutions were used in airtight packages, without direct contact of the seed with the solution.

Table 1. Relative humidity (\%) as a function of temperature and saturated solutions used.

\begin{tabular}{cccccc}
\hline \multirow{2}{*}{ Saturated solution } & \multicolumn{5}{c}{ Temperature $\left({ }^{\circ} \mathbf{C}\right)$} \\
\cline { 2 - 5 } & $\mathbf{5}$ & $\mathbf{1 0}$ & $\mathbf{1 5}$ & $\mathbf{2 0}$ & $\mathbf{2 5}$ \\
\hline Potassium hydroxide & 13.0 & 12.3 & 9.0 & 8.5 & 8.0 \\
Potassium acetate & 24.8 & 23.5 & 23.5 & 23.0 & 22.5 \\
Magnesium chloride & 34.0 & 33.5 & 33.5 & 33.0 & 32.5 \\
Potassium carbonate & 43.0 & 44.0 & 44.0 & 44.0 & 43.2 \\
Calcium nitrate & 61.5 & 61.0 & 58.0 & 56.0 & 52.8 \\
Sodium chloride & 76.0 & 76.0 & 75.5 & 75.3 & 75.2 \\
Potassium chloride & 87.8 & 87.0 & 86.0 & 85.0 & 84.3 \\
Barium chloride & 91.5 & 91.4 & 91.2 & 90.8 & 90.4 \\
\hline
\end{tabular}

During the evaluation period, the seeds were weighed until reaching constant mass, and then the dry mass of the product was determined, then the dry mass of the product was determined by the oven with forced air circulation $\left(105 \pm 3{ }^{\circ} \mathrm{C}\right.$ during 24 hours) and the result expressed in dry base moisture (\%db). The hygroscopic process was estimated using theoretical models (modified Henderson, Chung-Pfost, Oswin and BET) for comparison and determination of the most appropriate to the experimental data.

The data were subjected to analysis of variance, by the $\mathrm{F}$ test, and regression analysis for the different temperatures and theoretical models, with dynamic equations of water in the seeds being determined, and the respective coefficient of determination $\left(R^{2}\right)$. To compare the theoretical models with the experimental data, the relative error and the estimated error were analyzed.

Pearson's linear correlation analysis was performed between the variables temperature and relative humidity with the water content. Considering the interaction of temperature and relative humidity, multivariate analysis was performed, the result being presented in threedimensional surface and determined model equation and respective determination coefficient. For data analysis, the software SISVAR (FERREIRA, 2019), Microsoft Excell ${ }^{\circledR}$ and SURFER ${ }^{\circledR}$ were used. 


\section{Results and discussion}

The equilibrium humidity of peanut seeds was influenced by temperature, relative humidity and the interaction of these factors, characteristic of the hygroscopic process (WENNECK et al., 2020; BUSTOS-VANEGAS et al., 2018). Considering the constant temperature, with variation of the relative humidity of the storage environment, it is possible to estimate the water content of the seeds under different conditions of relative humidity of the environment by mathematical models (Table 2).

Table 2. Parameters of regression models for experimental isothermal conditions in peanut seeds.

\begin{tabular}{ccccc}
\hline \multirow{2}{*}{ Temperature $\left({ }^{\circ} \mathbf{C}\right)$} & \multicolumn{3}{c}{ Parameters } & \multirow{2}{*}{$\mathbf{R}^{\mathbf{2}}$} \\
\cline { 2 - 4 } 5 & 0.3706 & $\mathbf{b}$ & $\mathbf{C}$ & 0.91 \\
10 & 0.3336 & -0.2244 & 0.0844 & 0.0743 \\
15 & 0.2761 & -0.1623 & 0.0597 & 0.93 \\
20 & 0.3329 & -0.2306 & 0.0789 & 0.95 \\
25 & 0.2627 & -0.1174 & 0.0573 & 0.97 \\
$5-25$ & 0.3706 & -0.2574 & 0.0844 & 0.92 \\
\hline
\end{tabular}

The knowledge of the isothermal sorption models allows to obtain important information for the handling, associating preventive measures to the maintenance of the quality of the product (AGHAZADEH et al., 2021; WENNECK et al., 2020). The sorption process can alter the characteristics of the seed microstructure (MALLEK-AYADI et al., 2020), and the water content influences the thermodynamic properties of the product (CAMPOS et al., 2019).

Considering the interaction of the storage conditions in the equilibrium water content, a multivariate analysis of the data was performed, obtaining the response surface as shown in Figure 1. In multivariate analysis of the experimental data, the response equation
(Equation 1) of the storage conditions on the equilibrium water content was obtained, with a coefficient of determination of 0.72 . Considering the parameters of the equation for each factor and also the calculated linear correlation, in which the water content in the seeds has a correlation equal to 0.85 for relative humidity and 0.005 for temperature observes more significant changes as a function of relative humidity.

$\mathrm{EH}=0.694+(0.02192 * \mathrm{~T})+(0.12866 * \mathrm{RH})$ (Equation 1)

Where,

$\mathrm{EH}=$ Equilibrium humidity $(\% \mathrm{db})$;

$\mathrm{T}=$ Temperature $\left({ }^{\circ} \mathrm{C}\right)$;

$\mathrm{RH}=$ Relative humidity (\%).

Figure 1. Response surface of the moisture content in peanut seeds as a function of temperature and relative humidity of the ambient air.

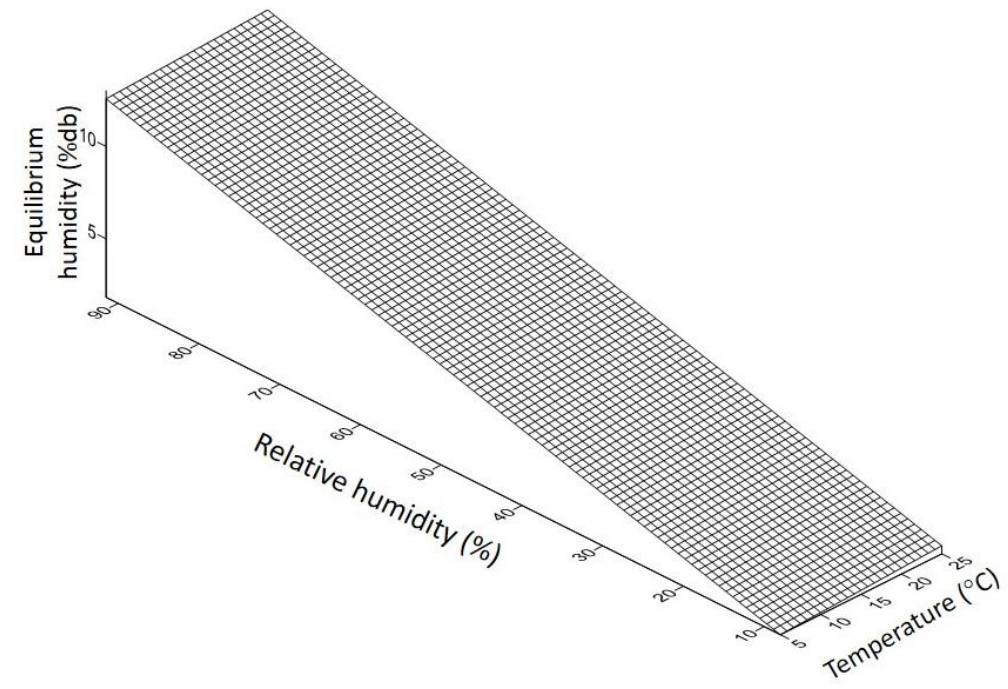


As the consumption of peanuts is directly in natural or in a processed form, the conditions of relative humidity and water content can influence the quality, presence of microorganisms and mycotoxins (SAATH et al., 2021).

Although experimental data

demonstrates the effect of conditions on the sorption process, adjustment with mathematical models is necessary to understand the isothermal process. The experimental data were fitted to the modified Henderson, Chung-Pfost, Oswin and BET models with parameters shown in table 3.

Table 3. Estimated parameters, coefficient of determination $\left(R^{2}\right)$, relative error $(P)$ and estimated error (SE) of the water sorption model in stored peanut seeds.

\begin{tabular}{|c|c|c|c|c|c|c|}
\hline \multirow{2}{*}{ Model } & \multicolumn{3}{|c|}{ Parameters } & \multirow{2}{*}{$\mathbf{R}^{2}$} & \multirow{2}{*}{$\mathrm{P}(\%)$} & \multirow{2}{*}{ SE (decimal) } \\
\hline & $\mathbf{a}$ & b & c & & & \\
\hline modified Henderson & 0.1932 & 0.0401 & 0.0317 & 0.99 & 23.29 & 0.0436 \\
\hline Chung-Pfost & 0.0924 & 0.0296 & 0.0379 & 0.99 & 4.86 & 0.0156 \\
\hline Oswin & 0.0959 & -0.0122 & 0.0305 & 0.98 & 35.21 & 0.0219 \\
\hline BET & 0.891 & -0.6005 & 0.0989 & 0.93 & 93.59 & 0.0483 \\
\hline
\end{tabular}

The Chung-Pfost model more accurately describes the hygroscopic process in peanut seeds, considering the smallest relative error $(\mathrm{P})$ among the mathematical models analyzed (Table 3). Based on the relative error, the modified Henderson, Oswin and BET mathematical models do not adequately describe the water sorption process in peanut seeds, under the conditions analyzed, since the relative error is greater than $10 \%$ (MOHAPATRA; RAO, 2005).
Considering the mathematical model Chung-Pfost, equilibrium moisture of peanut seeds was estimated under different temperature and relative humidity conditions (Figure 2). Equilibrium moisture is stable as a function of temperature increase, as in quinoa seeds according to Bustos-Vanegas et al. (2018), of grapes according to Aghazadeh et al. (2021) and pumpkin Wenneck et al. (2020).

Figure 2. Equilibrium humidity estimated by the Chung-Pfost model for different temperature $(5,10,15,20$ and $\left.25^{\circ} \mathrm{C}\right)$.

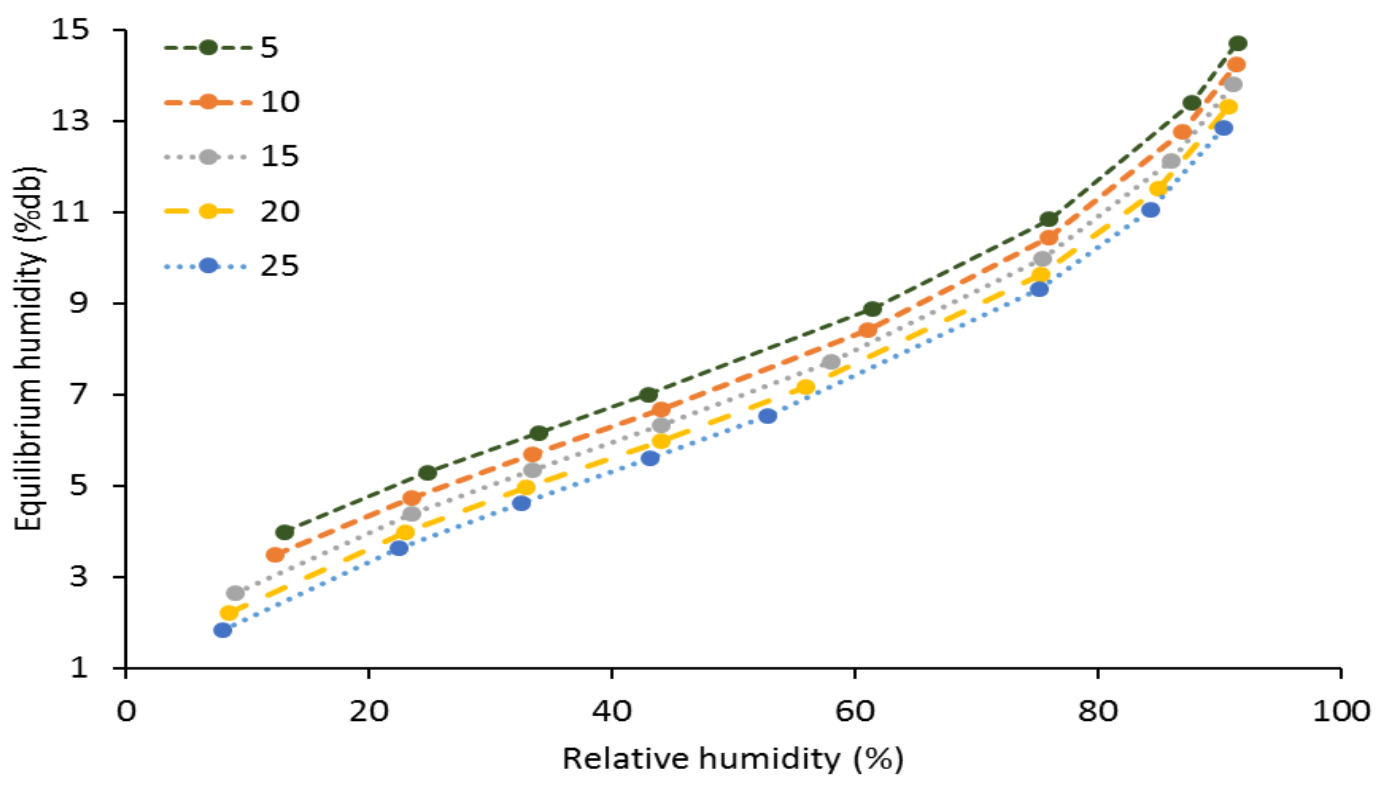


The relative humidity and temperature conditions that the product enters into equilibrium, regardless of the time to condition affect the integrity of the membrane structure, the commercial quality and the physiological potential of the product, reflecting the enzymatic and biochemical reactions that the conditions trigger in the seed (RESENDE; OLIVEIRA, 2013; SAATH et al., 2010; SAATH et al., 2021; ZIEGLER et al., 2017; WENNECK et al., 2020).

In peanut seeds, the water content influences the germination percentage, making the product storage with low humidity more suitable (SÁ et al., 2020). Considering the conditions of the storage environment, it is possible to define strategies to maintain the quality of peanut seeds in order to maintain thermodynamic and physiological properties.

\section{Conclusions}

The relative humidity of the environment has a greater expression on the equilibrium water content.

The Chung-Pfost model was the most suitable to represent the sorption process in peanut seeds.

\section{Acknowledgments}

The Coordenação de Aperfeiçoamento de Pessoal de Nível Superior (CAPES), the Conselho Nacional de Desenvolvimento Científico e Tecnológico (CNPq), the Fundação Araucária and the Universidade Estadual de Maringá (UEM).

\section{References}

AGHAZADEH, N.; ESMAIILI, M.; MOHTARAMI, F. Prediction of equilibrium moisture contents of black grape seeds (Siah Sardasht cultivar) at various temperatures and relative humidity: shelf-life criteria. Nutrition and Food Sciences Research, v.8, n.1, p.45-52, 2021.

ARAUJO, D. J.; AZEREDO, G. A. DE; GUEDES, L. R.; SALES SILVA, J. H. C.; TARGINO, V. A. Conservação de sementes de feijão-caupi sob diferentes condições de armazenamento. Diversitas Journal, v.6, n.1, p.74-88, 2021. https://doi.org/10.17648/diversitas-journal-v6i1$\underline{1200}$

BUSTOS-VANEGAS, J. D.; CORRÊA, P. C.; ZEYMER, J. S.; BAPSTESTINI, F. M.; CAMPOS, R. C. Moisture sorption isotherms of quinoa seeds: thermodynamic analysis. Engenharia Agrícola, v.38, n.6, p.941-950,

2018.

https://doi.org/10.1590/1809-4430-

eng.agric.v38n6p941-950/2018

CAMPOS, R. C.; CORREA, P. C.; ZAIDAN, I. R.; ZAIDAN, Ú. R.; LEITE, R. A. Moisture sorption isotherms of sunflower seeds: Thermodynamic analysis. Ciência e Agrotecnologia, v.43, e011619, 2019. https://doi.org/10.1590/1413$\underline{7054201943011619}$

FERREIRA, D. F. SISVAR: a computer analysis system to fixed effects split plot type designs. Revista Brasileira de Biometria, v. 37, n.4, p.529535, 2019. https://doi.org/10.28951/rbb.v37i4.450

LARIOS, L. M. O.; GORAYEB, T. C. C. Avaliação da Comercialização e Certificação do amendoim (Arachis Hypogaea L.) e Derivados do município de São José do Rio Preto, SP. Mobilizar o Conhecimento para Alimentar o Brasil, p.613626, 2016.

MALLEK-AYADI, S.; BAHLOUL, N.; KECHAOU, N. Mathematical modelling of water sorption isotherms and thermodynamic properties of Cucumis melo L. seeds. LWT, v.131, e109727, 2020. https://doi.org/10.1016/j.Iwt.2020.109727

MOHAPATRA, D.; RAO, P.S. A thin layer drying model of parboiled wheat. Journal of Food Engineering, v.66, n.4, p.513-518, 2005. https://doi.org/10.1016/i.jfoodeng.2004.04.023

ROLLEMBERG, N. C.; FERRAO, B. C. F.; MARQUES, J. P.; SOARES, C. E. S.; DUTRA, M. O.; RÜNTZEL, C. L.; SILVA, B. A.; SIMAO, V.; SUSSEL, V. M. Ocorrencia de Aflatoxinas em Amendoim e Produtos Derivados. In: Conferencia Brasileira de Pós-Colheita, 7. Associação Brasileira de Póscolheita ABRAPOS. Anais [...]., 2018. p.10251030.

http://eventos.abrapos.org.br/anais/paperfile/91 o 20181103 03-13-52 913.pdf

SÁ, N. O.; WENNECK, G. S.; SAATH, R. Peanut storage with different water content conditions. International Research Journal of Advanced Engineering and Science, v.6, n.1, p.1-4, 2020.

SAATH, R.; BORÉM, F. M.; ALVES, E.; TAVEIRA, J.H.S.; MEDICE, R. Microscopia eletrônica de varredura do endosperma de café (Coffea arabica 
L.) durante $\mathrm{o}$ processo de secagem. Ciência e Agrotecnologia, v.34, n.1, p.196-203, 2010. https://doi.org/10.1590/S1413$\underline{70542010000100025}$

SAATH, R.; WENNECK, G. S.; SANTI, D. C.; REZENDE, R.; ARAUJO, L. L. Gestão da qualidade na pós-colheita do amendoim como ferramenta à competitividade. Revista em Agronegócio e Meio Ambiente, v.14, n.1, e007927, 2021. https://doi.org/10.17765/2176-

9168.2021v14n1e007927.

TUBBS, T.; BARIBUTSA, D.; WOLOSHUK, C. Impact of opening hermetic storage bags on grain quality, fungal growth and aflatoxin accumulation. Journal of Stored Products Research, v.69, v.1, p.276-281, 2016. https://doi.org/10.1016/i.jspr.2016.10.003

WENNECK, G. S.; SAATH, R.; SANTI, D. C.; ARAÚJO, L. L.; SANTOS, J. P.; OLIVEIRA, G. G. F. Hygroscopic balance in pumpkin seeds. Revista de Agricultura Neotropical, v.7, n.2, p.17-26, 2020. https://doi.org/10.32404/rean.v7i2.4090

ZIEGLER, V.; FERREIRA, C. D.; TONIETO, L.; SILVA, J. G.; OLIVEIRA, M.; ELIAS, M. C. Efeitos da temperatura de armazenamento de grãos de arroz integral de pericarpo pardo, preto e vermelho sobre as propriedades físico-químicas e de pasta. Brazilian Journal of Food Technology, v.20, e2016051, 2017. https://doi.org/10.1590/1981-6723.5116

ZUCARELI, C.; BRZEZINSKI, C. R.; ABATI, J.; WERNER, F.; RAMOS JUNIOR, E. U.; NAKAGAWA, J. Qualidade fisiológica de sementes de feijão carioca armazenadas em diferentes ambientes. Revista Brasileira Engenharia Agrícola e Ambiental, v.9, n.8, p.803-809, 2015. https://doi.org/10.1590/1807-

1929/agriambi.v19n8p803-809 